\title{
The Palatability of the Concept Indigenous People in Ethiopian Constitutional System
}

\author{
Mulu Bzayene Lemma \\ Department of Civics and Ethical Studies, Raya University, Maichew, Ethiopia
}

\begin{abstract}
Ethiopia is a multi-ethnic, multi-cultural, multi-lingual country. There are more than eighty nations, nationalities and people and more than 200 dialects in the country. Because of this the FRDE Constitution recognizes that every nations, nationalities and people of the country has the right to speak, to write and to develop its own language; to express, to develop and to promote its culture; and to preserve its history as well as the right to free land for grazing and cultivation as well as the right not to be displaced from their own lands but not the right of the indigenous people to own traditional lands, territories and resources their economic and social development and to their very survival as distinct cultural communities. The main objective of this paper is to examine the palatability of the concept indigenous people in Ethiopia Constitutional System. In doing so, legal and scholarly books were reviewed. So, as far as constitution is the supreme law of the country, the palatability of the concept indigenous people in the constitution is essentially important for the observance of the right of the indigenous people in Ethiopia. This paper analyzes that there is no constitutional provision in favor of the recognition of the rights of the indigenous people to own and use land for their survival in Ethiopia. Besides, the government argues that there is not any official statistics that identifies who are indigenous and who are not in the Ethiopia. This paper recommends that if the right of the indigenous people should be observed the concept of indigenous people should be explicitly justified in FDRE Ethiopian constitutional system.
\end{abstract}

Keywords: Indigenous people, Human Rights, Constitutional system, FDRE

DOI: $10.7176 / \mathrm{JLPG} / 95-01$

Publication date:March $31^{\text {st }} 2020$

\section{INTRODUCTION}

Human rights have become the most common and leading international standards to measure all over the activities of human life. Recently, new human right issues have been welcoming to the international scene like the right to indigenous people. As a response to the growing component of international human rights law, the United Nation has been formulating numerous legal paramount covenants, conventions, declarations, resolutions and comments including the United Nations Declaration on the Right to Indigenous People. The Declaration on the Right to Indigenous People was formulated for indigenous people in September 2007.

This is because of various national and international indigenous peoples' organizations that mobilize since 1970s, which led to the development of international human rights instruments concerned with the rights of indigenous people. For instance, national indigenous organizations developed through the 1960s in Australia, Canada and the United States, with Central and South America following in the 1970s. ${ }^{1}$ At the same time, the international organizations of indigenous peoples also emerged largely in the 1970s. The first international conference of non-governmental organizations on indigenous issues and the NGO Conference on Discrimination against Indigenous Populations were held in Geneva in 1977 and came up with producing a Declaration of Principles for the Defense of the Indigenous Nations and Peoples of the Western Hemisphere, and others. ${ }^{2}$

After all, Indigenous peoples are recognized to have the "right to the full enjoyment, as a collective or as individuals, of all human rights and fundamental freedoms as recognized in the Charter of the United Nations, the Universal Declaration of Human Rights and international human rights law". ${ }^{3}$ These rights are namely the right to self-determination and political participation, to own their land, territories and resources, to maintain their culture, language and socio-economic well-being to mention. However, as it will highlighted at the next part, the concept and the contents of right brought in favor were weak still and contentious even during the of process of the adoption of the declaration. To be precise, the controversies of the conceptual clarity and the content of rights that would afford to indigenous people are the challenges that faced by the declaration since its inception. ${ }^{4}$

Because of this, the declaration was adopted with one hundred -forty three nations voted in favor while only four voted against it and eleven abstained with thirty- four nations absent including Ethiopia, the concern of this paper. ${ }^{5}$ This implies us that the reluctance of states as if Ethiopia to ratify the declaration may be one because of

\footnotetext{
${ }^{1}$ See, Gray, A., (1997), Indigenous Rights and Development; Self-Determination in an Amazonian

${ }^{2}$ See, Niezen, Ronald (2003); the Origins of Indigenism: Human Rights and Political Identity, Berkeley: University of California Press. 21

${ }^{3}$ See, United Nations Declaration on the Rights of Indigenous people, article 1, (2007)

${ }^{4}$ See, Amelia Cook \& Jeremy Sarkin Who Is Indigenous?: Indigenous Rights Globally, in Africa, and Among the San in Botswana, (2009),

5 See, S James Anaya (2010), “The evolution of the concept of Indigenous peoples and its contemporary dimensions", In: Perspectives on the rights of minorities and indigenous peoples in Africa, Solomon Dersso (ed.): Pretoria University Law Press. pp. 23-42.
} 
the controversies mentioned above, albeit they have ratified other binding international human rights instruments viz. UDHR, ICCPR and ICESCR that the foundations for the formulation of this declaration as legal response to indigenous people as human groups.

The paper organizes into three parts. The first part will highlight the reasons why there has been so much difficulty in arriving at a consensus on the concept and contents of indigenous people's right. The second part will analyze the major human rights pertaining to indigenous people. The third part, which is the main focus of the paper, will evaluate the validity of applying the indigenous peoples' rights in Ethiopia constitutional system. Finally, it will end by concluding remarks of the writer.

\section{Indigenous People in General}

Though it is not surprising to find controversies on the concept of indigenous people since contention is common over all human rights issues, there are various and challenging tensions to identify who are indigenous people from different parts of the globe, which made the concept to be without a universally agreed definition to date. Regarding to our attempt to understand the concept of indigenous people a short and brief analysis of the controversies seems imperative for the purpose of the paper. Hence, let us see some of the arguments as follow;

As a get way to my writing as Niezen (2003) observes that the controversies on the term "indigenous people" is not only because of the rationales/ because of objectives of the struggles the international movement of indigenous people's advocates but also the diversified historical, social, cultural and political experiences of the people they had and have so far. In other words, the historical, political, social and cultural divergence becomes the challenges to come up with a universally accepted definition. Let us see some of the tensions, which have because of these differences of the globe. ${ }^{1}$

In a way, let us start from the definition that cited in (Solomon, 2010, Niezen, 2009) of UN Special Rapporteur José Martinez Cobo "Indigenous communities, Peoples and nations are those which having historical continuity with pre-colonial societies that developed on their territories, consider themselves distinct from other sections of societies now prevailing in those territories or parts of them. They form at present non dominant sectors of society and are determined to preserve, develop and transmit to future generations their ancestral territories and their ethnic identity, as the basis of their continued existence as peoples in accordance with their own cultural patterns, social institutions and legal systems". ${ }^{2}$

This definition shows that the centrality of the attachment of indigenous peoples to their territories and the historical continuity of their existence on their ancestral territories from pre-colonial times. Besides, it highlights that currently they are living in their lands. Finally, it indicates that they are determined to transmit their ancestral territories to future generations. In short, historical continuity that requires the people to "currently occupy their ancestral territories" "3, self-identification as peculiar from other section of societies, and an aspiration of transmitting their identity to the future generations are markers to regard human groups as indigenous people.

José Martinez Cobo's definition is, nevertheless, subject to claim from some part of the globe as instances from the Southeast Asia as they are considered themselves as indigenous people vis-à-vis "complex patterns of displacement and movements of peoples across national boundaries". ${ }^{4}$ As also cited in Niezen (2003), James Anaya has pointed out that no matter either, the indigenous people are still at their ancestral land or not, whilst they have deeper attachments to their lands, these communities and nations are considered as indigenous for the sake of compromising Cobo's definition with the people who are not currently occupy their ancestral lands. ${ }^{5}$

Similarly in Africa, following the recommendation of the International Working Group for Indigenous in 1999 as African Commission on Human and Peoples Rights need to be encouraged to work towards the recognition of the rights of indigenous peoples in Africa, the commission has opposed José Martinez Cobo's proposed definition. This is because that it argued as Cobo's definition focuses on the colonial aspects as it is irrelevant in the African context and "ultimately any African can legitimately consider him/ herself as indigenous". ${ }^{6}$ Besides to this, it argued that this definition in the context of Africa could be viewed as problematic since its emphasis is being 'being first' and in most African countries nearly all communities are actually 'pre-colonial' in the sense of being 'original' to the continent. While such a criterion of identification might be effective in countries that have witnessed large colonial settlements, it may not be applicable to the situation of much of Africa. ${ }^{7}$

Because of the closed and persuasive arguments of the commission, the Working Group of Experts was

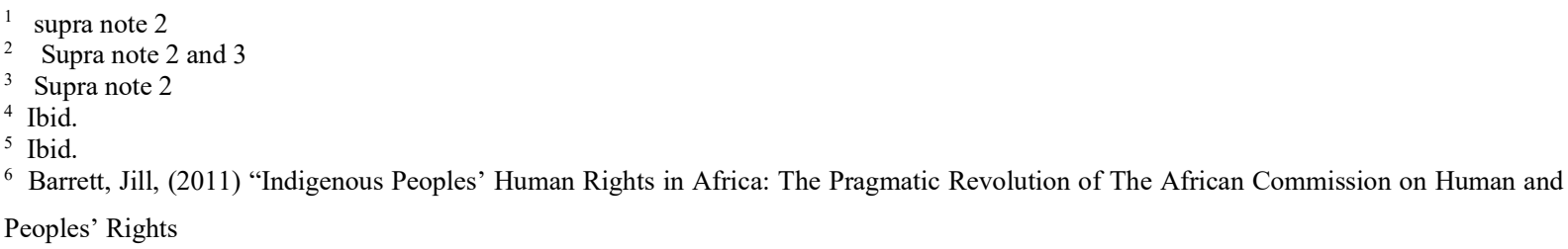


established in 2000 mandated to "examine who are indigenous and implications of Banjul charter and well being of indigenous communities". This is in order to address the problems raised by the Commission concerning the applicability of the concept of indigenous people's rights in the context of Africa so far. ${ }^{1}$

According to its mandate, the working Group in its report came up with the criteria those have to be considered whilst there is an attempt of defining the concept of indigenous people in Africa. Accordingly, has concluded that one of the primary characteristics of indigenous communities in Africa is that they have suffered discrimination and marginalization. Besides the cultural life, the extent of their attachment to land, inaccessibility and isolation, subject to political domination and self-identification are also the critical criteria of defining the concept indigenous people in Africa. ${ }^{2}$ Similarly, Adem has also quoted that "historical marginalization and isolation from mainstream politics and economic life, and spiritual or cultural attachment to land and the natural resources thereon" used, as a criteria is more proper than aboriginality. ${ }^{3}$ This means, unlike José Martinez Cobo's, what the African working group has done is simply setting of criteria to identify indigenous people.

So, these very few arguments shows us that the concept of indigenous people has faced by conceptual contentions related with the historical, social, political and cultural difference of societies from the world and has failed to have a single universally accepted definition. However, this does not mean that the definition of the UN Special Rapporteur José Martinez Cobo is not the most widely accepted and authoritative definition up to date ${ }^{4}$.

\section{Major Human Rights pertaining to Indigenous people}

In addition to the contentions on the understanding of the concept indigenous people, there are also very challenging controversial arguments on the recognition of the human rights of indigenous people. prior proceeding with the discuss of the major human rights relevant to indigenous people highlighting some surrounding arguments and controversies on the indigenous peoples rights seems imperative. Hence, let us see some of the arguments as follow;

Interestingly, as it has been commonly raised while there is an attempt to have a convention, resolutions and declaration on a specific human right like child, women, minorities, development, persons with disability and others, there are also "critics of the usefulness or points of linking specific rights to indigenous groups argue that there is no justification for a specific canon of rights". ${ }^{5}$ This is because they believed that international laws that recognized all human rights without any hierarchy and prerequisite for all are enough to protect and promote the human rights of all human beings including indigenous people. ${ }^{6}$ In short, on need of declaration on the rights of indigenous people since there are any specific human rights of indigenous people but people.

Related to this, India also rejected the claim rights of indigenous people, as all citizens are sons and daughters of the soil; none may legitimately claim an identity based on having occupied the territory first. India has supplemented the "we-are-all-indigenous" argument as it suspect as it leads to chauvinist claims by groups all over India. ${ }^{7}$

Similarly, the Morocco government in a 1985 statement to the Working Group on Indigenous Populations has also noted, "the problem of the rights of indigenous populations does not arise in Morocco since all citizens, whether living in the town or the country, enjoy the same rights and are subject to the same obligations".

Therefore, these are some of the pre texts rationalize by states to ignore the recognition of indigenous peoples' rights in its territory. As Adam quoted this might be related with recognition their basic rights sometimes challenging with the interest of states in development policies, projects and investments. ${ }^{8}$

When we look at the major human rights pertained to indigenous people, as I have mentioned earlier indigenous peoples have the right to self-determination, the right to land and resources, to maintain their cultures, and to be asked for their free, prior and informed consent in decisions. ${ }^{9}$ These have been stated in many international legal instruments including international covenants of ICCPR and ICESCR and UNDRIP. In African legal regimes, too, these rights are included in Banjul charter. Hence, I will try to deal with the places of these rights in the United Nation Declaration on the Right to Indigenous people to aforementioned legal instruments.

As long as indigenous people are closely related with self-determination, indigenous people are recognized the right to self-determination expressly under article 3 of UNDRIP as well as through the international covenants of ICCPR and ICESCR the "right to Self-determination". This means, people have recognized to make decisions 
on over all civil, political, economic, social and cultural affairs that affects their live, albeit the covenants entered into arguments in using the concept "people". ${ }^{1}$ Regarding to this, after long discussions and arguments among legal experts and practitioners, the Human Rights committee clearly articulated that self-determination as a right of people means that it is a collective right but not an individual and it concerned more about the subsistence of indigenous peoples whose lands and livelihoods may be under threat. ${ }^{2}$ Accordingly, indigenous people have recognized to self-determination in the umbrella of people.

Indigenous peoples are also related with the "rights to own traditional lands, territories and resources" 3 their economic and social development and to their very survival as distinct cultural communities, to decide their own priorities for the process of development, to control over their own economic, social and cultural development. In light to this, the UNDRIP through article 28(1) request states, if respect and protect the aforementioned indigenous peoples' rights is not possible, to make "just, fair and equitable compensation, for the lands, territories and resources which they have traditionally owned with ${ }^{4}$ " by considering "their free and informed consent" 5 into consideration. In this context, "land, territories and resources are collective rights, which do not apply beyond the context of indigenous people". 6 Therefore, indigenous people have recognized the right to own traditional lands, territories and resources and right to free, prior and informed consent.

Indigenous people need recognition of cultural rights as far as it is their distinctive character from other section of society. Indigenous people are recognized to practice, improve, develop their cultural traditions and customs, and states are required to make the required effort to enable them exercise their rights appropriately. ${ }^{7}$ Again, indigenous people are also related with the right not to be subject to any discriminatory conditions to "exercise right to education, to access information and media, as well as labor". 8

\section{The Palatability of the Concept Indigenous Peoples in Ethiopia}

As has already been mentioned at the first part of the paper, there is no single universal definition of the concept indigenous people. Even in Ethiopia, there is a conceptual ambiguity and vagueness in identifying who are indigenous people and who are not so far. Since lack of conceptual clarity has been challenging to reach at consensus on the declaration of the right of Indigenous people, there is also similar problem to recognize indigenous people in Ethiopia too. Here is the concern of the paper which we will evaluate the validity of applying indigenous people in Ethiopian constitutional system.

FDRE Constitution came up with federal arrangement, the units of which are nations, nationalities and peoples of Ethiopia guarantying the right to Self- determination of ethnic groups/ nations which include the right to practice their culture, speak and develop their language; promote their history, self-administration within specific territory up to secession and representation at both levels of governments.

Additionally, the constitution has clearly defined who are 'nation, nationalities and people' through article 39(5); "group of people who have or share large measure of a common culture or similar customs, mutual intelligibility of language, belief in a common or related identities, a common psychological make-up, and who inhabit an identifiable, predominantly contiguous territory". ${ }^{9}$

Here, what we can understand from this is that the FDRE constitution does not recognize any conceptual difference among 'nation, nationality and people'. Accordingly, the constitution has expressly recognize every 'nation, nationality, people' to have an unconditional right to self-determination up to secession, which means that they have recognized the right to use their own language, to express and promote their culture, to self-rule and to shared rule at all levels without regard of any preconditions.. ${ }^{10}$ At the same time, the right to land is enshrined under article 40/ 3 and 6 of the constitution to nation, nationalities and people as their "common property". 11 Therefore, 'nation, nationalities and people' means those who are known as Ethiopian people and have the right to self-determination up to secession, the right to culture, language, and the right to own land.

In order to assess whether the application of indigenous people not only in Ethiopia constitutional system but also throughout the world, is valid or not agreed definition of the concept is critical, however, as stated earlier there are conflicting definitions of the concept at the international and regional level.

Just after the African Working Group on Indigenous people has listed in its report some people in Africa who are applying the term "indigenous" to themselves. From Ethiopia the working group mentioned that Somalis, Afars,

\footnotetext{
Supra note 6

Ibid.

Supra note 4

Ibid. Article 28

Ibid. Article 32/2

Supra note 10 , P.29

Supra note 4, article 11, 12, 13 and 14

Ibid. article 12(2), 16(1) and 17(3)

FDRE constitution, article 39 (5)

${ }^{10}$ Ibid. article $39(1,2)$

Ibid. article $40(3,6)$
} 
Borana, Kereyu (Oromo), Nuer as indigenous peoples.

The arguments on the concept indigenous people in Ethiopia have begun by the Ethiopian delegate's objection on the authenticity of the statistics and identification of certain groups as being indigenous peoples in Ethiopia. ${ }^{1}$ The delegate has viewed that ", to the best of his knowledge, there were no official statistics relied upon to make conclusions about groups who could be identified as indigenous in the country". "In other words, the objection of the delegate reflects that the concept of indigenous people is not applicable in Ethiopia as there is no official statistics that has identified these are indigenous people and these are not rather as I have mentioned above the constitution has stated 'nation, nationalities and people' as Ethiopian people.

To the contrary, Yonatan and Beken have identified the Berta, the Gumuz, Shinasha, the Mao and Komo as an indigenous people of the Benishangul-Gumuz regional state, and the Agew Himra, Awi and Oromo groups in Amhara regional state, and Irob and Kunama in Tigray are indigenous minorities. ${ }^{3}$ At the same time, Dereje has noted that the Nuer, the Anywaa, the Majagir, and the Opo and the Komo are indigenous people since 1991. Although these are linguistically related and engage in various forms of integrationist and /or assimilation process like inter ethnic-marriage over time. ${ }^{4}$ This shows us that scholars are defining the term "indigenous people" in Ethiopia from different perspective because of the absence conceptual confrontation is the effect of lack of universally agreed definition of indigenous people.

From the very beginning, it is not valid to define any part of societies without having an internationally/ universally accepted definition and even to draft human rights declaration without right holders like the United Nations Declaration on the Rights of Indigenous people in 2007. Next, why we are arguing about is to make indigenous people recognized in Ethiopia constitutional system to have the right to Self- determination which includes the right to practice their culture, speak and develop their language; promote their history, selfadministration within specific territory up to secession and representation at both levels of governments that have already afforded to the 'nation, nationality and people'. To this end, what value adds from the recognition of some part of the nation, nationalities and people as indigenous people as far all Ethiopian nation, nationalities and people are recognized as equally as the constitution looks for. Rather recognizing indigenous people as specific right holders of the aforementioned rights in Ethiopia would create a tension among nation, nationalities and people and political instability at the states.

\section{Conclusion}

In conclusion, since human right by its nature is about the relationship between the right-holders and duty-bearers, the indigenous people as a right holder have to be defined very clearly and the duty bearers simultaneously at the declaration which is looking for. That is why the concept of indigenous people is more contentious and vague.

In our case, instead of arguing in favor of the applicability of indigenous people in a states like Ethiopia that comprises more than 80 nation, nationalities and people which have necessarily one and same definition as multiethnic groups and validated them to be the sovereign power of the country. It is paramount important whilst the arguments are about the implementing and monitoring mechanism of those rights that have already recognized to nation, nationalities and people in Ethiopia constitution.

Lastly, as far as the FDRE constitution has recognized the right to self- determination which include the right to practice their culture, speak and develop their language; promote their history, self-administration within specific territory up to secession and representation at both levels of governments, and to own land for 'nation, nationalities and people'. Those who are looking to be recognized as indigenous people can fully entertain their right that have afforded by the UN declaration as the name of nation, nationalities and people as well since recognizing indigenous people means recognize them the right that have already given to nation, nationalities and people. Therefore, legitimatize indigenous people in Ethiopia context is not as such valid.

\section{References}

- Adem K. Abebe, (2011), "Limitations To The Rights Of Indigenous Peoples In Africa: A Model For Balancing National Interest In Development with The Rights Of Indigenous Peoples?”,( African Journal of International and Comparative Law 20.3 (2012): Edinburgh University Press. pp.407-422

- Amelia Cook \& Jeremy Sarkin Who Is Indigenous?: Indigenous Rights Globally, in Africa, and Among the San in Botswana, (2009),

- Amelia Cook \& Jeremy Sarkin, ((2009)) Who Is Indigenous?: Indigenous Rights Globally, in Africa, and Among the San in Botswana

\footnotetext{
${ }^{1}$ Ibid.

${ }^{2}$ Ibid

${ }^{3}$ Yonatan Tesfaye and C. Beken, ETHNIC FEDERALISM AND INTERNAL MINORITIES: THE LEGAL PROTECTION OF INTERNAL MINORITIES IN ETHIOPIA, (2013), Edinburgh University Press

${ }^{4}$ Dereje Fayissa, Experience of Gambella regional states: in Ethnic federalism; The Ethiopian Experience in Comparative perspective, David Turton(ed) (2006)
} 
- Bahar Abdi, (2010), The Emerging International Law on Indigenous Peoples' Rights: A Look at the Ethiopian Perspective

- Bojosi, N.Kealeboga, (2006) "Protecting indigenous peoples in Africa: An analysis of the approach of the African Commission on Human and Peoples' Rights” (6 Afr. Hum. Rts. L.J. 382).

- Dereje Fayissa, (2006), Experience of Gambella regional states: in Ethnic federalism; The Ethiopian Experience in Comparative perspective David Turton(ed)

- Gray, A., (1997), Indigenous Rights and Development; Self-Determination in an Amazonian

- $\quad$ M. Özden, \&Ch. Golay THE RIGHT OF PEOPLES TO SELF-DETERMINATION AND TO PERMANENT SOVEREIGNTY OVER THEIR NATURAL RESOURCES SEEN FROM A HUMAN RIGHTS PERSPECTIVE

- $\quad$ Niezen, Ronald (2003); the Origins of Indigenism: Human Rights and Political Identity, Berkeley: University of California Press

- $\quad$ Patrick Thornberry,(2002), Indigenous peoples and human rights, , Manchester University Press; available at www.manchesteruniversitypress.co.uk

- $\quad$ Report of The African Commission's Working Group of Experts on Indigenous Populations/Communities, at its 28th ordinary session, 2005. Session held in Cotonou, Benin in October 2000.

- S James Anaya (2010), "The evolution of the concept of Indigenous peoples and its contemporary dimensions", In: Perspectives on the rights of minorities and indigenous peoples in Africa, Solomon Dersso (ed.): Pretoria University Law Press. pp. 23-42.

- Sarah Vaughan, (2006); Responses to Ethnic federalism in Ethiopia's Southern Region: In Ethnic federalism; The Ethiopian Experience in Comparative perspective, David Turton(ed)

- Tokuma Daba (2010); The Legal and Practical Protection of the Rights of Minorities in Self Administering Nations of Ethiopia: The Case of Oromia

- Yonatan Tesfaye and C. Beken, (2013), ETHNIC FEDERALISM AND INTERNAL MINORITIES: THE LEGAL PROTECTION OF INTERNAL MINORITIES IN ETHIOPIA, Edinburgh University Press 